Journal of Agri-Food Science and Technolgy

Journal homepage http://journal2.uad.ac.id/index.php/jafost

\title{
Effectivity of Trichoderma harzianum as Bio-fungicide Against Moler Disease and Bio-stimulator of Shallot Growth
}

\author{
Icha Rusita ${ }^{1}$, Hadi Sasongko ${ }^{1}$ \\ ${ }^{1}$ Biology Study Program, Faculty of Applied Science and Technology, Universitas Ahmad Dahlan, \\ Yogyakarta, Indonesia \\ Corresponding Author: icha.rusita@staff.uad.ac.id
}

ARTICLE INFO

Keywords:

Moler Disease

Biofungicide

Biostimulator

Trichoderma-

harzianum

\begin{abstract}
Moler disease is the primary disease that disturbs the shallot' cultivation. Hence, it is beneficial to have preventive measures to mitigate the risk and to improve growth. The research objective is to know the effectivity of Trichoderma harzianum suspension as a biofungicide and bio-stimulator. The study used seven treatments, i.e., immersion of shallot seeds on negative control (distilled water), positive control (synthetic fungicide+ZPT $1 \mathrm{~g} /$ liter), T.harzianum suspension with different concentrations of 2 ppm, 4 ppm, 6 ppm, 8 ppm, and $10 \mathrm{ppm}$, assigned in a Completely Randomized Design (CRD). Treatment that results in a significant level will be continued to the Least Significance Different (LSD) 5\% test. The observed variables are the intensity of moler disease and the growth of shallot seeds. Experiment results show the significant difference between treatments. The optimal treatment to reduce the percentage of moler disease intensity is the immersion of shallot seeds in 10 ppm-concentrated T.harzianum suspension, while to improve the shallot growth is in 8 ppm-concentrated T.harzianum suspension. The intensity of moler disease has a negative correlation to the plant's height and leaf's diameter but shows no correlation pattern to the number of leaves, wet weight, dry weight, and length of roots.
\end{abstract}

\section{INTRODUCTION}

Shallot (Allium sp.) is one of the vegetable commodities which gets the public and government attention (Latarang and Syakur, 2006). According to the Central Statistic Agency and Indonesia Directorate General of Hogriculture, the production of shallot in 2015 decreased as 4800 tons compared to the previous year. The production decline, is assumed as one of the reasons why the shallot's price increased in 2016. The decreased productivity of shallot in Indonesia is caused by the nonoptimal cultivation technique, the lack of excellent and certified seeds, and the strike of pests and diseases. The most common disease found in the cultivation of shallot is the moler disease which is caused by a fungus named as Fusarium oxysporum. An early symptom is indicated by the yellowing 
leaves which soon will turn into crinked leaves. The crinkled leaves then will be rotten. The infected root changes into dark brown in color and will be rotten. The emersion of the disease is assumed to be caused by cultivation techniques which are not optimal yet. Hence, preventive actions, such as using high quality seeds and giving treatments to seeds before planting, are required to avoid the moler disease to arise. However, farmers tend to choose synthetic fungicides to overcome the disease.

Synthetic fungicides only work in the soil's surface and cannot reach the plant's system. Its impact on the pathogen is not optimal. Therefore, bio-agent as an alternative that can kill pathogenic fungus is necessary. Based on the research made by Alfizar et al. (2013), Trichoderma sp. can do in vitro inhibition of the growth of pathogenic fungus Fusarium sp., Colletotrichum capsici, and S. rolfsii. The finding is supported by Deden and Umiyati (2017) statement that the treatment of Trichoderma harzianum and Trichodema koningii suspension with concentration as $2.5 \mathrm{ppm}$ showed the rate of moler disease infection less than 1\%. The use of Trichoderma sp. in solid formulation shows the less optimal result, when compared to the liquid formulation as in previous research. Shofiyani and Suyadi (2014) support this statement by saying that the Trichoderma sp. applied in solid formula showed the intensity of disease as $66.22 \%$ with a dose of $30 \mathrm{~g} / \mathrm{hole}$. While according to Juwanda et al., (2016), $66.22 \%$ of intensity is still vulnerable to the strike of moler disease.

Nurhidayati et al. (2013) also stated that Trichoderma sp., which grown in coconut water as growth media, can increase the number and viability of spores, and suppressed the intensity of rotten-disease in chili. The growth of Trichoderma sp. on coconut water waste as media, has the highest population growth $300 \times 10^{7} \mathrm{cfu} / \mathrm{g}$ compared to Potato Dextrose (PD), vegetable water waste, and fish water waste as growth medium (Mariyam et al., 2017). Therefore, Trichoderma sp. can also be a bio-stimulator for plant's growth aside from its role as bio-agent. Trichoderma sp. positively affects the rooting, number of leaves, and production of a plant, so it also can be called as Plant Growth Enhancer (Setyadi et al., 2017).

The effective concentration of Trichoderma harzianum suspension specifically for reducing moler disease intensity, as well as enhancing the growth of shallot cultivation, have never reported yet. The research objectives were to determine the optimal concentration of Trichoderma harzianum suspension on coconut water to reduce the intensity of moler disease infection, the optimal concentration to enhance the growth of shallot, and the correlation between the intensity of moler disease and the growth parameters of cultivation in shallots.

\section{RESEARCH METHODS AND MATERIALS}

The study was held from January to February 2018. Tools used in the research are Laminar Air Flow (LAF), autoclave, Memmert oven, measuring flask 1000ml, Erlenmeyer flask $300 \mathrm{ml}$, measuring pipette $1 \mathrm{ml}, 5 \mathrm{ml}, 10 \mathrm{ml}$, round Ose-needle, test tube, and calipers. Meanwhile, materials used are Crok Kuning cultivars shallot seeds, Trichoderma harzianum inoculum, Potato Dextrose Agar (PDA) as media, Fussarium sp. inoculum, soil, manure, coconut water, a synthetic fungicide with tebuconazole as an active ingredient.

The research was assigned in a Completely Randomized Design (CRD), with 4 treatments and 7 repetitions. The independent variable in this research is the concentration of Trichoderma harzianum suspension with 5 variants of concentrations as $2 \mathrm{ppm}, 4 \mathrm{ppm}$, 6 ppm, 8 ppm, 10 ppm, which compared by two control treatments, i.e., positive and negative control. Positive control treatment as synthetic fungicide with tebuconazole and $\mathrm{ZPT}$ with concentration as $1 \mathrm{~g} / \mathrm{l}$ as active ingredients. In the meantime, the negative control 
treatment is sterilized water.

Observed variables in this research are the intensity of moler disease on shallot and the growth of the cultivar. Growth parameters that are observed in this research are the height of the plant, diameter of leaves, number of leaves, dry weight, wet weight, and the length of the root.

Data are analyzed by using analysis of variance (ANOVA) with confidence interval as $95 \%$. If the test is found in a significant difference, the data analysis will be continued to the Least Significance Difference (LSD) with confidence interval as 95\%.

\section{RESULT AND DISCUSSIONS}

Interaction between pathogen with its host can be seen in the occurrence of symptoms of a disease. A Fussarium sp. pathogen, which is infected to a growing media, will cause moler disease if it is supported by the suitable environment temperature and humidity level. Immunity of the host to pathogen infections can be shown in a percentage of disease' intensity and the period of infections. Yunasfi (2002) also added that temperature, light intensity, and humidity could affect the growth of fungus as pathogens that infect cultivars. Fusarium sp. optimally grows in $\pm 30^{\circ} \mathrm{C}$ with humidity level in an interval of $75-90 \%$. Based on observations done in Green House Biology Universitas Ahmad Dahlan (UAD ) Indonesia, each treatment affects differently to the percentage of moler disease' intensity in shallots. The intensity of disease is obtained based on the calculation of infection level, which is by observing the number of infected and uninfected leaves.

Table 1. Percentage of Moler Disease' Intensity and Effectiveness Rate of Trichoderma harzianum.

\begin{tabular}{|c|c|c|c|c|c|}
\hline \multirow[b]{2}{*}{$\begin{array}{l}\text { Treat- } \\
\text { ment }\end{array}$} & \multicolumn{2}{|c|}{ Number of leaves } & \multirow{2}{*}{$\begin{array}{l}\text { Intensity of } \\
\text { infection } \\
(\%)\end{array}$} & \multirow{2}{*}{$\begin{array}{c}\text { Intensity } \\
\text { of disease } \\
(\%)\end{array}$} & \multirow{2}{*}{$\begin{array}{c}\text { Effectivity of } \\
\text { Trichoderma } \\
\text { harzianum } \\
\text { (\%) }\end{array}$} \\
\hline & $\begin{array}{c}\sum_{\text {infec }} \\
\text {-ted }\end{array}$ & $\sum_{\begin{array}{c}\sum_{\text {uninfec- }} \\
\text { ted }\end{array}}$ & & & \\
\hline $\mathrm{P}$ & 3 & 98 & $2.21^{\mathrm{a}}$ & $2.98^{\mathrm{a}}$ & 0 \\
\hline $\mathrm{N}$ & 32 & 82 & $5.21^{b}$ & $27.19^{\mathrm{d}}$ & 0 \\
\hline P1 & 23 & 89 & $2.63^{\mathrm{a}}$ & $17.92^{\mathrm{cd}}$ & 34.09 \\
\hline $\mathrm{P} 2$ & 25 & 107 & $2.21^{\mathrm{a}}$ & $17.91^{\mathrm{cd}}$ & 34.13 \\
\hline P3 & 16 & 78 & $2.78^{\mathrm{a}}$ & $15.33^{b c}$ & 43.61 \\
\hline $\mathrm{P} 4$ & 5 & 83 & $4.09^{\mathrm{ab}}$ & $5.96^{\mathrm{ab}}$ & 78.08 \\
\hline P5 & 5 & 95 & $3.22^{\mathrm{ab}}$ & $4.77^{\mathrm{a}}$ & 82.45 \\
\hline \multicolumn{3}{|c|}{ LSD $5 \%$} & 2.32 & 9.61 & \\
\hline
\end{tabular}

HST=day after planting; $\mathrm{P}=$ synthetic fungicide with tebuconazole $+\mathrm{ZPT} ; \mathrm{N}=$ sterilized aquades; $\mathrm{P} 1=$ Tharzianum 2 ppm-concentrated suspension; $\mathrm{P} 2=$ Tharzianum 4 ppm-concentrated suspension; P3=T.harzianum 6 ppm-concentrated suspension; P4=T.harzianum 8 ppm-concentrated suspension; $\mathrm{P} 5=$ T.harzianum $10 \mathrm{ppm}$-concentrated suspension. The average score which followed by the same letter on the same column indicates there is no significant difference of LSD 5\% test

Based on the experiment results in Table 1, the highest rate of effectiveness is found at $10 \mathrm{ppm}$ concentration as $82.45 \%$, while the lowest is at $2 \mathrm{ppm}$ concentration as $34.09 \%$. It means that the immersion of shallots in T.harzianum was more optimal to reduce the moler disease' intensity compared to the shallots which were immersed only in aquades. It happened because T.harzianum has the property of not easily dissolves in 
water. Its mycelium is able to attach to the soil and root, which then protects the rooting system of the host.

The immersion of shallot seeds in T.harzianum suspension also affects the growth of the plant. Growth parameters that are measured in this research include the plant's height, the diameter of leaves, and the number of leaves. The growth of the plant is affected by two supporting factors, i.e., external and internal factors. If either one or both of them fail to support, then the growth and development of the plant will not go well (Buntoro et al., 2014). An effort that can be done besides fertilization is the use of bioagents, which can improve the growth of plants.

Table 2. The impact of immersion of shallot seeds in coconut water as growing media of Trichoderma harzianum to the growth parameters.

\begin{tabular}{cccccccc}
\hline \multirow{2}{*}{ Treatment } & \multicolumn{7}{c}{ Parameter } \\
\cline { 2 - 8 } & $\begin{array}{c}\text { Initial } \\
\text { weight } \\
(\text { gram })\end{array}$ & $\begin{array}{c}\text { Plant's } \\
\text { height } \\
(\mathrm{cm})\end{array}$ & $\begin{array}{c}\text { Diameter } \\
\text { of leaves } \\
(\mathrm{mm})\end{array}$ & $\begin{array}{c}\text { Number } \\
\text { of } \\
\text { leaves }\end{array}$ & $\begin{array}{c}\text { Wet } \\
\text { weight } \\
(\text { gram })\end{array}$ & $\begin{array}{c}\text { Dry } \\
\text { weight } \\
(\text { gram })\end{array}$ & $\begin{array}{c}\text { Root's } \\
\text { length } \\
(\mathrm{cm})\end{array}$ \\
\hline P & 6.45 & $46.01^{\mathrm{cd}}$ & $2.80^{\mathrm{a}}$ & $31.75^{\mathrm{de}}$ & $7.72^{\mathrm{bc}}$ & $0.82^{\mathrm{c}}$ & $11.47^{\mathrm{c}}$ \\
$\mathrm{N}$ & 6.58 & $27.50^{\mathrm{a}}$ & $1.15^{\mathrm{a}}$ & $21.00^{\mathrm{bc}}$ & $5.17^{\mathrm{a}}$ & $0.50^{\mathrm{a}}$ & $6.50^{\mathrm{b}}$ \\
P1 & 6.44 & $40.47^{\mathrm{bcd}}$ & $2.22^{\mathrm{cd}}$ & $24.75^{\mathrm{bc}}$ & $8.575^{\mathrm{c}}$ & $0.74^{\mathrm{bc}}$ & $11.82^{\mathrm{c}}$ \\
P2 & 6.50 & $28.28^{\mathrm{a}}$ & $1.82^{\mathrm{bc}}$ & $19.25^{\mathrm{ab}}$ & $3.79^{\mathrm{a}}$ & $0.39^{\mathrm{a}}$ & $3.37^{\mathrm{ab}}$ \\
P3 & 6.48 & $36.43^{\mathrm{b}}$ & $1.3^{\mathrm{ab}}$ & $14.75^{\mathrm{a}}$ & $4.072^{\mathrm{a}}$ & $0.52^{\mathrm{ab}}$ & $2.62^{\mathrm{a}}$ \\
P4 & 6.68 & $47.15^{\mathrm{d}}$ & $2.53^{\mathrm{de}}$ & $35.00^{\mathrm{e}}$ & $10.45^{\mathrm{c}}$ & $0.86^{\mathrm{c}}$ & $12.42^{\mathrm{c}}$ \\
P5 & 6.49 & $39.60^{\mathrm{bc}}$ & $1.92^{\mathrm{c}}$ & $26.25^{\mathrm{cd}}$ & $5.66^{\mathrm{ab}}$ & $0.52^{\mathrm{ab}}$ & $5.55^{\mathrm{ab}}$ \\
\hline LSD 5 \% test & 7.198 & 0.512 & 6.033 & 3.381 & 0.227 & 3.812 \\
\hline
\end{tabular}

Table 3. Correlation analysis result between observed variables of shallot cultivation.

\begin{tabular}{cccccccc}
\hline Parameter & IP & TT & DD & JHD & BB & BK & PA \\
\hline IP & 1 & & & & & & \\
TT & $-0.835^{*}$ & 1 & & & & & \\
DD & $-0.759^{*}$ & $0.826^{*}$ & 1 & & & & \\
JHD & -0.685 & $0.789^{*}$ & $0.856^{*}$ & 1 & & & \\
BB & -0.459 & $0.807^{*}$ & $0.763^{*}$ & $0.870^{*}$ & 1 & & \\
BK & -0.551 & $0.891^{* *}$ & $0.807^{*}$ & $0.830^{*}$ & $0.938^{* *}$ & 1 & \\
PA & -0.375 & 0.734 & $0.787^{*}$ & $0.852^{*}$ & $0.954^{* *}$ & $0.932 * *$ & 1 \\
\hline
\end{tabular}

*Correlation is significant at the 0.05 level, **Correlation is significant at the 0.05 level. IP:disease's intensity; TT=height of plant; $\mathrm{DD}=$ diameter of leaves; JHD=number of leaves; $\mathrm{BB}=$ wet weight; $\mathrm{BK}=\mathrm{dry}$ weight; $\mathrm{PA}=$ root's length.

Based on the measurement of the plant's height, shallot that treated with immersion in T.harzianum formulation with the concentration of $8 \mathrm{ppm}$ shows the highest result among all other treatments, which is $47.15 \mathrm{~cm}$ in height (as in Table 2.). Contreras-Cornejo et al. (2009) proposed that Trichoderma is able to produce indole-3-acetic acid (IAA), which stimulates the lateral root growth of Arabidopsis thaliana. Moreover, Akladious and Abbas (2012) added that the treatment of seeds before planting with T.harzianum suspension is more effective in increasing the plant's growth parameters. The forming of leaves in number is affected by the number of minerals absorbed by roots, which functionates in the formation and division of cells. The formation of the number of leaves is influenced by nutrients absorbed by the roots that function in the formation and division of cells. Based on experiment data on Table 2, the T.harzianum 8 ppm-concentrated 
formulation is able to increase the number of leaves to 35 leaves. Meanwhile, the least number of leaves is 14.75 with the concentration of formulation as $6 \mathrm{ppm}$.

The number of leaves is a growth parameter which is closely related to the fresh weight of shallot plants. The number of leaves in a clump depends on the number of layers of onion bulbs. Based on the correlation test results in Table 3, the number of leaves positively correlates to the fresh weight of shallot plants. The fresh weight of shallot plants shows the amount of water in the tissue. The length of the root also profoundly affects the plant's growth, although it is not absolute. Observation results show that the highest length of the root is $12.42 \mathrm{~cm}$ on the suspension of T.harzianum in $8 \mathrm{ppm}$ concentration. The immersion in T.harzianum with a concentration of $8 \mathrm{ppm}$, showed the morphology of fresh plant with roots' tendency to be longer. Besides, the length of the root also can affect the wet weight of a plant. The length of the root of shallot plants positively correlates to the wet weight of the plant. The success rate of a plant in absorbing nutrients and water affects the productivity of the plant. Meanwhile, the dry weight is closely related to the accumulation of organic compounds, especially carbohydrates, which its formation is dependent on the rate of photosynthesis (Kaeni et al., 2014).

Shallots that treated with that treatment is assumed to be able to absorb water more optimal among other treatments so that it can have a better wet weight which is 10.45 gram. Furthermore, the weight of shallot plants also experienced the most significant increase in the immersion of T.harzianum formulation with a concentration of $8 \mathrm{ppm}$, which is 3.77 grams compared with the initial bulb weight. The shallots then are put into the oven to get the dry weight. The dry weight of the sample treated with T.harzianum 8 ppm-concentrated formulation is 0.86 grams, which means there is a shrinkage of 9.59 grams from the wet weight.

\section{CONCLUSIONS}

Based on discussions about the effectivity of Trichoderma harzianum as biofungicide to moler disease and bio-stimulator to the growth of shallot cultivation, it can be concluded that the optimal concentration of T.harzianum to reduce the intensity of moler disease in shallots is $10 \mathrm{ppm}$. Meanwhile, the optimal suspension of T.harzianum to increase the growth cultivation of shallots is concentrated at $8 \mathrm{ppm}$. The intensity of moler disease and the growth parameter of shallots indicates a correlation. The intensity of moler disease negatively correlates to the height of the plant and diameter of leaves but does not correlate with the number of leaves, wet weight, dry weight, and length of the root.

\section{BIBLIOGRAPHY}

Alfizar, Marlina, \& Susanti, F. (2013). Kemampuan Antagonis Trichoderma Sp. Terhadap Beberapa Jamur Patogen In Vitro. J.Floratek, 8, 45-51.

Buntoro, B. H., Rogomulyo, R., \& Trisnowati, S. (2014). Pengaruh Takaran Pupuk Kandang dan Intensitas Cahaya Terhadap Pertumbuhan dan Hasil Temu Putih ( Curcuma zedoaria L.). Vegetalika, 3(4), 29-39.

Contreras-Cornejo, H. A., Macias-Rodriguez, L., Cortes-Penagos, C., \& Lopez-Bucio, J. (2009). Trichoderma virens, a Plant Beneficial Fungus, Enhances Biomass Production and Promotes Lateral Root Growth through an Auxin-Dependent Mechanism in Arabidopsis. Plant Physiology, 149(3), 1579-1592.

Deden, \& Umiyati, U. (2017). Pengaruh inokulasi Trichoderma sp. dan varietas bawang merah terhadap penyakit moler dan hasil tanaman bawang merah (Allium ascalonicum L) The effect of Trichoderma sp. inoculation and shallot "Bawang merah" variety on moler diseases and yield of shallo. Jurnal Kultivasi, 16(2), 340-348.

Juwanda, M., Khotimah, K., dan Amin, M. (2016). Peningkatan Ketahanan Bawang Merah 
Terhadap Penyakit Layu Fusarium Melalui Induksi Ketahanan dengan Asam Salisilat Secara Invitro. Agrin, 20(1), 15-28.

Kaeni, E., Toekidjo, dan Subandiyah, S. (2014). Efektivitas Suhu dan Lama Perendaman Bibit Empat kultivar Bawang Merah (Allium cepa L. Kelompok Aggregatum) Pada Pertumbuhan dan Daya Tanggapnya Terhadap Penyakit Moler. Vegetalika, 3(1), 5365.

Latarang Burhanuddin, \& Syakur, A. (2006). Pertumbuhan dan Hasil Bawang Merah (Allium ascalonicum L) pada Berbagai Dosis Pupuk Kandang. J. Agroland, 13(3), 265-269.

Mariyam, S., Nion, Y. A., Dan, \& Asie, E. R. (2017). Limbah Pasar Tradisional Sebagai Alternatif Perbanyakan Agensia Hayati Trichoderma sp (The waste of market traditional as propagation alternatif of biocontrol agent Trichoderma sp). In Seminar Nasional Rapat Tahunan BKS-PTN.

Nurhidayati, S., Majid, A., \& Mihardjo, P. A. (2013). Pemanfaatan Biofungisida Cair Berbahan Aktif Trichoderma sp. Untuk Mengendalikan Penyakit Antraknosa (Colletotrichum Sp) pada Cabai Di Lapang. Berkala ilmiah Pertanian, $x$, 1-5.

Setyadi, I. M. D., Artha, I. N., \& Wirya, G. N. A. S. (2017). Efektifitas Pemberian Kompos Trichoderma Sp . Terhadap Pertumbuhan Tanaman Cabai (Capsicum annum L). EJurnal Agroekoteknologi Tropika, 6(1), 21-30.

Shofiyani, A., \& Suyadi, A. (2014). Kajian Efektifitas Penggunaan Agensia Hayati Trichoderma sp. Untuk Mengendalikan Penyakit Layu Fussarium Pada Tanaman Bawang Merah Diluar Musim Program Studi Agrotek Fakultas Pertanian Universitas Muhammadiyah Purwokerto. In Prosiding Seminar Hasil Penelitian LPPM UMP (pp. 1-7). Purwokerto.

Yunasfi. (2002). Faktor-faktor yang Mempengaruhi Perkembangan Penyakit dan Penyakit yang Disebabkan oleh Jamur. Seminar, (1987), 1-7. 